Marquette University

e-Publications@Marquette

$1-1-2001$

The "Risky Business" of Binge Drinking Among College Students: Using Risk Models for PSAs and Anti-Drinking Campaigns

Joyce M. Wolburg

Marquette University, joyce.wolburg@marquette.edu

Accepted version. Journal of Advertising, Vol. 30, No. 4 (Winter 2001): 23-39. DOI.@ 2001

Routledge (M.E. Sharpe). Used with permission. 
NOT THE PUBLISHED VERSION; this is the author's final, peer-reviewed manuscript. The published version may be accessed by following the link in the citation at the bottom of the page.

\title{
The "Risky Business" of Binge Drinking Among College Students: Using Risk Models for PSAs and Anti-Drinking Campaigns
}

\author{
Joyce M. Wolburg \\ Diederich College of Communication, Marquette University \\ Milwaukee, WI
}

To assist creators of public service announcements and anti-drinking campaigns, this study provides an in-depth examination of the risks of binge drinking from the perspective of college students. Using current risk models for guidance, key elements from the qualitative data in the study are addressed, including perceived risks and their severity, vulnerability to risks, self-efficacy, response efficacy, benefits from ritual functions, and other costs or benefits based on students' attitudes and beliefs. An integrated risk perception model is introduced.

Student participants enumerated extensive risks; however, they generally felt invulnerable to the consequences. Most adopted a management style of "taking chances" when binge drinking because they perceived a built-in safety net in the college environment. Three ritual functions and various attitudes and beliefs help explain why a cost and benefit analysis favors binge drinking. Recommendations are given. 
There are risks to drinking alcohol, but sometimes you really don't care at all. All you want to do is get as drunk as possible. And most times you could care less what happens as long as you have a good time and wake up the next morning in your own bed-usually with such a severe hangover that you are completely useless for the entire day, sometimes two (student \#15).

Binge drinking, the excessive consumption of alcohol, continues to be one of the most challenging problems facing college campuses. Despite unprecedented campaigns against binge drinking, defined as men who consume five or more drinks at a single sitting and women who consume four or more, heavy drinking has actually increased (Marcus 2000). The number of students who drink with the intent of getting drunk has increased from $40 \%$ to $47 \%$, and the number of "frequent" binge drinkers, defined as those who hinged at least three times in the last two weeks, has increased from $20 \%$ to $23 \%$ (Wechsler et al. 2000). Other statistics (Wechsler et al. 2000) show that the national percentage of students who binge drink has held steady at 44\% from 1993 to 1999.

Admittedly, any attempt to quantify binge drinking raises valid questions, such as whether five or more drinks leads to the same amount of impairment (and subsequent likelihood of negative consequences) among all drinkers. However, concepts such as impairment present challenges for measurement. At a minimum, level of impairment must address the amount of food consumption that accompanies drinking, mood states of the person, and the time frame of the single sitting, which may be as few as one or two hours or as many as eight or ten hours. Perhaps these complexities have resulted in the widespread acceptance of Wechsler and colleagues' (1995, 2000) definition, which is based simply on quantity rather than on the level of impairment that accompanies excessive consumption.

Most colleges and universities expect and tolerate a certain amount of consumption among students but find the negative consequences of excessive drinking problematic. Total abstinence among students is not usually the goal of campaigns; decreases in binge drinking often are. By attempting to decrease binge drinking, most colleges and universities believe that the negative outcomes will 
likewise diminish. Various initiatives have been used to lower the incidence of binge drinking, but most have not achieved the hoped for level of success (Mendelson 2000). For example, after a five-year, $\$ 770,000$ effort to curb binge drinking at the University of Delaware, the campus has not demonstrated the expected "culture shift," and the percentage of students who binge only dropped from $62 \%$ to $59 \%$ (O'Sullivan 2001).

Other statistics are equally sobering. According to information from the Center for Science in the Public Interest (Had Enough Campaign 2001), college students annually spend $\$ 5.5$ billion on alcohol, which is more than they spend for books, soft drinks, and other nonalcoholic drinks combined. In addition, more undergraduates are expected to die from alcohol-related causes than will later receive master's and doctoral degrees combined. Finally, crime statistics show that $95 \%$ of violent crime and $80 \%$ of all vandalism on campus is alcohol related. Alcohol is implicated in $90 \%$ of all reported rapes. One-quarter to one-third of college women have experienced sexual assault, and approximately $85 \%$ of those incidents were date rapes (Simon 1993).

Other undesirable outcomes of binge drinking are well established, including unplanned and unsafe sexual activity (Wechsler et al. 1995), sexual assaults (Abbey et al. 1996), being arrested or ticketed (Wechsler et al. 1995), illegal drug use (Schneider and Morris 1991), being a passenger with an intoxicated driver (Schneider and Morris 1991), poor academic performance (Presley, Meilman, and Lyerla 1993), and driving while intoxicated (West et al. 1996). A common misperception is that the problem of drinking and driving has been "solved." Although alcohol-related traffic fatalities decreased $36 \%$ from 1980 to 1995 , more recent figures show an increase in fatalities (Roan 2001). The National Highway Traffic Safety Administration (200 1) reports that $40 \%$ of all traffic fatalities in 2000 (16,653 actual deaths) were alcohol related, up 4\% from 1999 figures. Thus, the problem of drinking and driving is still one that deserves careful attention.

Key to the discussion of binge drinking is the perception of risk, and of critical importance is the knowledge of whether behavior

Journal of Advertising, Vol 30, No. 4 (Winter 2001): pg. 23-39. DOI. This article is (C) Routledge (M.E. Sharpe) and permission has been granted for this version to appear in e-Publications@Marquette. Routledge (M.E. Sharpe) does not grant permission for this article to be further copied/distributed or hosted elsewhere without the express permission from Routledge (M.E. Sharpe). 
deemed "risky" by researchers, campus administrators, and healthcare practitioners is perceived as risky among students. Answers should help creators of public service announcements (PSAs) and antibinge-drinking interventions communicate more effectively with students. If students do not perceive risks associated with drinking, it is logical to assume that communicators must either change students' perception of risks or use a different tactic.

This study evaluates the theoretical perspectives addressing risk to provide a context for understanding binge drinking behavior. It then examines drinking within a ritual behavior model, evaluates message strategies from the alcohol industry and nonprofit organizations, and presents data from a qualitative study. The qualitative data are organized around theoretical constructs from the risk literature to achieve two goals: to gain insight into key components of students' perception of risk when binge drinking and to evaluate how adequately the behavior of binge drinking fits the various models. Finally, the study offers an integrated risk model and provides recommendations for creators of PSAs and anti-drinking campaigns.

\section{Theoretical Perspectives on Risky Behavior}

Risk can be understood from a variety of theoretical perspectives, including the Health Belief Model (HBM; Becker 1974; Janz and Becker 1984; Rosenstock 1991), the Protection Motivation Theory (PMT; Rogers 1975, 1983), and the Extended Parallel Process Model (EPPM; Witte 1992). These models are reviewed to gain insight into current thinking about risk and to evaluate the extent to which these perspectives either complement or compete against one another.

The HBM originally proposed that persons will take action to avoid or control ill-health conditions if four conditions are met: (1) if they believe the condition to have serious consequences or risks, (2) if they regard themselves as susceptible to the condition, (3) if they believe that a course of action would be beneficial in effectively reducing threats, and (4) if they believe that the anticipated rewards or benefits outweigh the perceived barriers for the course of action, such as inconveniences or unpleasantness (Becker 1974; Janz and 
Becker 1984; Rosenstock 1991). A later addition to the model is selfefficacy (Janz and Becker 1984l, which is based on earlier work by Bandura $(1977,1986)$ and addresses a person's confidence that he or she can successfully execute the desired behavior. When examining binge drinking within the HBM, students should theoretically drink less if they believe that (1) binge drinking will lead to serious physical or social consequences, such as alcohol poisoning or disgrace from losing control; (2) the consequences can happen to them; (3) drinking in moderation or abstaining will effectively prevent the serious consequences and will be regarded as beneficial behaviors; (4) the rewards of drinking less, such as avoiding alcohol poisoning and disgrace, are greater than the costs of such things as not fitting in with friends; and (5) they are personally capable of drinking less or not drinking at all. One limitation of the model is that it does not predict the outcome when some components are high and some are low.

The PMT (Maddux and Rogers 1983; Rogers 1975, 1983) addresses the same constructs as the HBM but offers some advantages by specifying the nature of the cognitive processes involved. Message components, such as information about the severity of a risky occurrence, are believed to trigger cognitive mediation, which in turn elicits protection motivation and helps people take action to control the danger they perceive. Protection motivation "has the typical characteristics of a motive: it arouses, sustains, and directs activity" (Rogers 1975, p. 98). The PMT focuses exclusively on the danger control process, which includes thoughts about the danger or threat and how to prevent it, rather than on the fear control process, which includes emotional responses such as denial. Fear control is addressed in other models (Leventhal 1970; Witte 1992).

Rogers (1983) assumes that protection motivation for the desired behavior (e.g., motivation to drink in moderation or abstain) is an additive function of six elements. Four are beliefs that operate in a positive linear function: (1) the threat is severe, (2) the person is vulnerable to the threat, (3) the person has the ability to perform the coping response, and (4) the coping response is effective in averting the threat. Two elements operate in a negative linear function: (1) the benefits from the maladaptive response, such as feeling relaxed and less stressed when binge drinking, and (2) the costs ofthe desired 
response, such as feeling socially isolated when abstaining or drinking in moderation. Thus, the highest amount of protection motivation will occur when all four positive elements are high and the two negatives are low (i.e., the person feels the threat is severe, his or her vulnerability is great, he or she can effectively perform the coping response, the coping response is perceived as efficacious, the maladaptive response offers few benefits, and the cost of the desired response is low). Rogers (1983) assumes that if either the severity of the threat or the person's vulnerability to the threat was perceived to be zero, no motivation would be aroused, regardless of the value of the other elements. Current researchers investigating anti-smoking messages continue to apply the model in the same way (Pechmann et al. 2001).

The main criticism that Witte (1992) levels against the PMT is that it fails to account for fear responses, which can overwhelm people and prevent them from effectively controlling danger. To correct this, Witte (1992) proposes the EPPM, which uses the PMT components of threat (severity and susceptibility) and efficacy (response efficacy and self-efficacy) but assumes two processes (danger control and fear control) instead of the PMT's single process (danger control). The dual process of the EPPM identifies a danger control response when a person takes action to avert a threat and a fear control response when the person expresses denial or avoidance behaviors (Roberto et al. 2000). The advantage of the EPPM is that, by adding the fear control response, it is possible to account for emotional responses when fear is aroused. When people perceive that they are at risk of a severe threat and they perceive high levels of efficacy, fear will motivate them to avoid the danger. However, if they are at risk from a severe threat but perceive low efficacy, fear will trigger an emotional response that increases their likelihood of denying the threat and engaging in behavior to reduce fear. Despite the advantage the model offers, the EPPM does not specify at what point the level of efficacy is sufficient to prevent a fear control response. In addition, the model does not account for costs and benefits of behavior.

The three models appear to be complementary, using a common core of concepts with some additional features specific to only one or two. All models incorporate the concepts of severity, susceptibility, 
response efficacy, and self-efficacy. Two models address the danger control process and the weighing of costs versus benefits, and one model addresses the fear control process. Although the control processes can only be inferred, all of these concepts are used in this study to evaluate the strategy of existing campaigns, guide research questions, organize data, offer a more comprehensive risk model, and make recommendations for future campaigns.

\section{Drinking as Ritual Behavior}

A useful framework for understanding some of the costs and benefits of alcohol consumption is the ritual behavior model. Rook (1985, p. 252) regards rituals as "a type of expressive, symbolic activity constructed of multiple behaviors that occur in a fixed, episodic sequence, and that tend to be repeated over time." They are "dramatically scripted" and "performed with formality, seriousness, and inner intensity" (Rook 1985, p. 252).

According to Rook (1985), every ritual has four components: (1) a ritual artifact; (2) a script, which describes the rules and procedures to be followed; (3) a performance, or the act of carrying out the ritual for members of the culture; and (4) an audience, or a significant component of the culture to observe the performance. Treise, Wolburg, and Otnes (1999) note that alcohol consumption among college students meets the criteria of ritual behavior because the consumption uses an artifact (alcohol), a script for students to follow (rules regarding how to obtain alcohol, when and where to drink), a performance role for the student (what drinks to order, how many drinks to consume, how to behave while drinking), and an audience (peers, bartenders, campus security).

Driver (1991) observes that rituals serve three functions or "social gifts"; they provide a sense of community, maintain order, and offer transformation. Treise, Wolburg, and Otnes (1999) observe that, when students drink with friends in a group, they establish a bond that fulfills the community function. When students observe the many rules associated with drinking, including how, when, and where to drink, they gain order and security in the social situation. Finally, when the alcohol releases inhibitions, alleviates stress, and offers a rite of 
passage, it transforms students from young adults who are anxious about social interactions to ones who are socially at ease. These three ritual functions are important because they may provide powerful benefits to binge drinking that in turn may compromise or interfere with intentions to modify behavior.

\section{Responsible Drinking Messages from the Alcohol Industry and Nonprofit Organizations}

Both the alcohol industry and nonprofit organizations have tried to influence binge drinking and underage drinking through responsibledrinking messages in the mass media. Current efforts from the beer industry shown on their respective web sites include Miller's longrunning "Think When You Drink" (2001) campaign, Coors's "21 means 21" (2001) campaign, and Anheuser-Busch's 'We all make a difference" (2001) campaign. Coors combines the "21 means 21" slogan with phrases such as "Go the distance" and "It's the right call." Budweiser combines the "make a difference" slogan with ads that show taxi drivers as "the original designated driver" and bartenders making customers "pass a bar exam." None of these campaigns addresses the severity of or susceptibility to the risks associated with drinking, nor do they explore costs and benefits. Instead, they address response and self-efficacy and do so with perhaps overly simplistic slogans. These efforts are open to the criticism that they accomplish the public relations goal of enhancing corporate image better than they modify behavior. Critics believe that industry efforts in the past may have increased awareness of alcohol issues but had little effect on behavior (Jacobs 1989). Furthermore, these messages are dwarfed in number by the product ads, which actively promote consumption (Rose 1991).

Nonprofit organizations have used messages in the form of PSAs that address a greater variety of constructs and do so more aggressively than do messages from alcohol companies. The Ad Council's campaigns (2001), such as "Friends don't let friends drive drunk" and "Take the keys, call a cab, take a stand," address efficacy quite explicitly, which is beneficial for those who are weak in selfefficacy. The Ad Council's effort at publicizing sobriety checkpoints intensifies both severity and susceptibility with the vivid slogan, "You 
drink and drive. You lose." A current campaign available on the Internet through the "Had Enough" web site of the Center for Science in the Public Interest works to create a social norm against binge drinking with the slogan "Binge Drinking Blows" (2001).

One difficulty in assessing the effectiveness of these messages is the limited media exposure. Unlike the alcohol industry's advertising spots, nonprofit organizations' PSAs are unpaid and placed at the discretion of the media company. Broadcasters choose to donate undesirable time slots that regular advertisers do not wish to purchase. With this system, spots are usually aired during the middle of the night or at other times that draw the smallest number of viewers (Gotthoffer and Lancaster 2001).

\section{Research Questions}

For anti-drinking PSAs and interventions to resonate with college students, further research is needed to gain insight into the students' perspective. This study asks the following seven research questions regarding the risks associated with binge drinking. The first three address risks, severity, and susceptibility.

RQ1: Do college students perceive any risks or threats associated with binge drinking? If so, what risks do they identify?

RQ2: How severe a threat do these risks pose?

RQ3: Do students feel vulnerable to these risks?

Questions 4 and 5 address response efficacy and self-efficacy, respectively.

RQ4: What behaviors do students engage in to manage or cope with the risk associated with binge drinking?

RQ5: What insights do they reveal regarding their ability to enact behaviors that can minimize risk associated with binge drinking?

Journal of Advertising, Vol 30, No. 4 (Winter 2001): pg. 23-39. DOI. This article is (C) Routledge (M.E. Sharpe) and permission has been granted for this version to appear in e-Publications@Marquette. Routledge (M.E. Sharpe) does not grant permission for this article to be further copied/distributed or hosted elsewhere without the express permission from Routledge (M.E. Sharpe). 
Questions 6 and 7 address costs and benefits. Because the literature identifies three social gifts or functions of ritualized drinking, RQ6 investigates what relative benefits they provide.

RQ6: Do the three ritual functions--community, order, and transformation--provide benefits from binge drinking that may need to be balanced against other factors?

The study concludes by probing for other attitudes and beliefs that may reveal other costs or rewards of binge drinking.

RQ7: Do students exhibit other attitudes or beliefs relevant to costs and benefits?

\section{Method}

\section{Design}

To explore the risks of binge drinking, a qualitative research design was used. Multiple data collection methods were used, including in-depth interviews, written essays, and focus groups. Focus groups served to provide an initial grounding for the researcher, and the essays and in-depth interviews generated the formal data analyzed in the study.

\section{Participants}

Participants for the study were chosen from a private, Midwestern university of approximately 10,000 students. The percentage of those who binge drink is estimated at $51 \%$, somewhat higher than the national average of $44 \%$ but typical of schools in the geographic region. The composition of the participants with regard to gender, race, and ethnic group closely mirrored the ratio of the university, with a slight overrepresentation of men and minorities. Participants for the focus groups were recruited within residence halls and were paid $\$ 5$ each; four groups of 5 students participated. Participants for the in-depth interviews were recruited through ads placed across campus and were paid $\$ 10$ each; 10 students 
participated. Participants for the written essays were students in introductory advertising and public relations classes who earned extra credit for typed essays of three pages in length; 51 students participated, which represented $57 \%$ of students enrolled in the classes. In all, 81 students participated.

To ground the researcher, members of a university task force for alcohol issues, including campus administrators, campus security officers, counselors, and student representatives, acted as key informants to the study. They were chosen on the basis of their knowledge, experience, and contact with students who binge drink (Lindlof 1995). For example, campus security officers provided information regarding behavior that requires police intervention, such as underage drinking, alcohol poisoning, injuries, date rape, and other crimes associated with drinking. An administrator from the Office of Student Affairs provided information regarding cooperation between the university and local bars and about university events that offer alternatives to drinking. The student representatives provided firsthand accounts of problems with other students who drink to excess.

Focus groups provided additional grounding. Questions covered a broad range of topics to alert the researcher to the most important issues and help in the development of relevant questions for the essays and in-depth interviews (Morgan 1988). Knowledge from focus groups and key informants not only served to provide a context for understanding issues related to risk, but also offered triangulation of the data.

Students in focus groups included all types of drinkers (binge drinkers, moderate drinkers, and abstainers) in order to gain insight from both those who enact the behavior and those who observe it. No qualifiers were used for participation in the essay writing so that all students were eligible for extra credit. Two additional extra credit options were offered to the students so that participants could receive extra credit without selecting the alcohol-related task. Participants wrote about their own drinking experiences or experiences with others who drink heavily. permission has been granted for this version to appear in e-Publications@Marquette. Routledge (M.E. Sharpe) does not grant permission for this article to be further copied/distributed or hosted elsewhere without the express permission from Routledge (M.E. Sharpe). 
NOT THE PUBLISHED VERSION; this is the author's final, peer-reviewed manuscript. The published version may be accessed by following the link in the citation at the bottom of the page.

Participants for the depth interviews were screened to include only those who meet the requirements of binge drinking (consumption of five or more drinks at a single sitting for men and four for women, with the occurrence of drinking at least once every two weeks). Three potential participants who responded to the recruitment posters were replaced; two drank only minimal amounts, and one was a visitor to campus and not a student.

\section{Procedure and Data Analysis}

Essays gathered from the 51 participants focused specifically on risk. Participants were asked to (1) note any situations that carry a degree of risk when drinking alcohol, what negative consequences might occur, and the likelihood of experiencing these consequences; (2) explain how to manage risk; (3) note any other attitudes that influence this decision; and (4) discuss any other behaviors that are potentially risky. The fourth question was asked to gain perspective for drinking relative to other risks students may encounter.

Individual depth interviews were conducted using an initial nondirective question (McCracken 1988) that asked participants to think about times they had been drinking and talk about one that was particularly memorable. Initial responses usually centered on heavy drinking episodes, and probes allowed students to elaborate on issues and focus on topics related to risk. Questions about risk followed the form of those used for the essays, with interviews lasting approximately one hour.

Focus group sessions and in-depth interviews were tape recorded and later transcribed; essays were written out by the participants. All data were analyzed using analytic induction and the constant comparison method to determine common themes (Glaser and Strauss 1967). By the end of the analysis, no new themes emerged, which indicated that the essays and in-depth interviews were adequate in number to reach the point of redundancy (Taylor 1994). permission has been granted for this version to appear in e-Publications@Marquette. Routledge (M.E. Sharpe) does not grant permission for this article to be further copied/distributed or hosted elsewhere without the express permission from Routledge (M.E. Sharpe). 
NOT THE PUBLISHED VERSION; this is the author's final, peer-reviewed manuscript. The published version may be accessed by following the link in the citation at the bottom of the page.

\section{Findings}

The data are organized around the following topics related to the research questions: perceived risks and their severity, vulnerability, response efficacy, self-efficacy, ritual influence, and the influence of other attitudes and beliefs.

\section{Perceived Risks and Their Severity}

When asked about their perception of risk to address RQ1 (Do college students perceive any risks associated with binge drinking? If so, what risks do they identify?), students were able to articulate no less than 13 different types of threats, all with potentially serious physical and social consequences. The following list of items identifies the type of risks that students believe they may encounter when drinking:

1. Drunken driving;

2. Other illegal situations-underage drinking and use offake IDs;

3. Sexual experiences including rape;

4. Passing out/losing control;

5. Fights;

6. Vandalism and destruction of property;

7. Physical illness, such as alcohol poisoning, hangovers, and alcoholism;

8. Physical injuries;

9. Emotional consequences-humiliation, guilt, hurt feelings, impaired judgment;

10.Drug use with alcohol;

11. Academic failure;

12. Financial consequences; and

13. Parental knowledge.

When asked about severity of these threats to address RQ2 (How severe a threat do these risks pose?), they dismissed the seriousness and compared the safety of drinking favorably against other potential hazards. The following three attitudes illustrate their thinking. 
NOT THE PUBLISHED VERSION; this is the author's final, peer-reviewed manuscript. The published version may be accessed by following the link in the citation at the bottom of the page.

The Consequences Are so Minimal. Despite the long list of possible outcomes previously noted, students have "gotten away with" drinking excessively with few serious consequences. The worst outcome that most personally expected was getting sick, and many students felt it was too minor to be concerned about.

What gives students confidence that they will be safe is this sentence--"nothing happens" (student \#12).

The only thing that will happen is the possibility of throwing up. Most college kids don't care if they get sick. It's a risk they are willing to take because they figure it's part of college life. Also, if they get sick, they figure they have the whole weekend to recuperate (student \#9).

Ironically, one negative outcome that many students fear is their parents' discovery of their drinking; "as far as being caught, some people don't care as long as their parents don't find out" (student \#26).

No One Disapproves of the Consequences. Because most students maintain enough distance to conceal their drinking behavior from their parents, peers are usually the only significant others who could approve or disapprove of their behavior. Regardless of what consequences follow episodes of binge drinking, students feel accepted by other students.

Peers are totally accepting and tolerant of these behaviors. Students know if they get sick from binge drinking, they don't have to face ridicule or scolding like they would if they were at home (student \#42).

Relatively Speaking, Drinking Is Safe. Students compare the risks of alcohol to other substances and regard alcohol as the safest drug around.

In comparison to other drugs, alcohol is safe. It's harder to get addicted to than most other drugs .... Alcohol is legal for people over 21 ... and binge drinking in college usually does not lead to a lifetime of alcohol abuse .... Moreover, alcohol is cheaper than any other drug, so the students can spend more money on

Journal of Advertising, Vol 30, No. 4 (Winter 2001): pg. 23-39. DOI. This article is (C) Routledge (M.E. Sharpe) and permission has been granted for this version to appear in e-Publications@Marquette. Routledge (M.E. Sharpe) does not grant permission for this article to be further copied/distributed or hosted elsewhere without the express permission from Routledge (M.E. Sharpe). 
NOT THE PUBLISHED VERSION; this is the author's final, peer-reviewed manuscript. The published version may be accessed by following the link in the citation at the bottom of the page.

their college tuition. For these reasons, I believe that alcohol is the safest drug that students can use (student \#39).

\section{Vulnerability}

To address RQ3 (Do students feel vulnerable to these risks?), the study examines students' thoughts and shows two powerful attitudes that undermine feelings of vulnerability.

We Are Invincible. Although it is clear that students recognize the potential for risk, they discounted the likelihood of being personally affected. A powerful belief is that they are "bulletproof' or "invincible," even when they are "trashed." Samples of their thoughts follow:

Feeling invincible is what gives us confidence that we will be safe. We hear the statistics of rape victims; yet, we feel it could never happen to us (student \#10).

We feel we are safe from harm, as if we are immortal and free from consequences. We feel we will live and party forever (student \#61).

Another related theme is that intoxication actually makes people safer from serious injuries. A student whose friend fell nearly 30 feet believed that being intoxicated was what saved his friend's life because his muscles were more relaxed; "He lived because he was drunk" (student \#52). He does, however, acknowledge that his friend probably would not have fallen if he had been sober.

Perhaps the most dramatic comment comes from a student who feels invincible to alcoholism, despite the devastation to people close to her.

I have watched the people I love most lose everything to drugs and alcohol, and yet I still drink in excess. My father is an alcoholic, and my 18-year-old brother is an alcoholic and a drug addict. About a year ago, we were a family ravaged by addiction and on the brink of disaster .... So why, after all the suffering that addiction has caused me and my family, do I continue to drink in excess, often to the point of alcoholism myself? The 
answer: I'm young, I'll live forever, and it will never happen to me (student \#12).

Almost All Students Drink; Therefore, It Must Be O.K. The second attitude that affects vulnerability is the conviction that drinking is a common, legitimized activity that almost everyone participates in without showing any fear of consequences. Because students see it as a norm, they fail to see how binge drinking can be risky. Those who do not drink heavily simply deviate from the norm, and those who drink reinforce the decision for others.

Alcohol consumption has become the norm on all college campuses. I think that students who do not consume alcohol on a regular basis or do not enjoy it are looked down upon or thought of as strange (student \#18).

Drinking is so common among college students that it has just been regarded as a favorite pastime. It is seen as a way to have fun ... this is why students have the confidence to consume large quantities of alcohol (student \#28).

\section{Response Efficacy}

To evaluate response efficacy in RQ4 (What behaviors do students engage in to manage or cope with the risk associated with binge drinking?), the study examines students' risk management behaviors and evaluates their effectiveness. When asked if students do anything to handle potential risks while drinking, the participants offered the following strategies.

Taking Chances. The overwhelming response to the question of risk management is that they do nothing; they simply take their chances because they believe the drinking environment is safe. When they take chances and suffer no consequences, the behavior appears to be self-reinforcing. The following comments give voice to those who do not consciously engage in any specific strategies to avoid risk:

Students take their chances because they are not thinking about safety when they are drinking. They feel invincible (student \#27). 
Most simply take their chances. They are not necessarily confident in being safe, but if they get away with it once, it becomes easy to master how to get away with whatever they are doing (student \#35).

When probed more closely, many students report that they do nothing because the drinking ritual already includes a variety of builtin behaviors that diminish the perception of risk. By far, the most common is to drink with friends.

Drinking with Friends, Choosing a "Babysitter." The motivation for drinking with friends probably has less to do with safety than with bonding, for one of the greatest benefits of drinking is that it affords a way of fitting in with others. However, the group setting provides the perception of safety, whether real or imagined, and plays a significant role in the way students drink.

I feel that when my friends and I collectively take our chances, the only reassurance we have is that our group of friends is very close knit and that we are continually looking out for each other (student \#51).

I know people who only drink with a certain group of people who they trust. They watch out for each other and never leave a party or a bar without the entire group (student \#3).

Some students say that all members of the group are generally watchful of one another with no particular member in charge; others formally appoint a "babysitter" or caretaker to watch over the safety of the other members of the group. Still others expect a member to informally volunteer to be the babysitter as the night goes on, usually the person who is drinking the least or is most comfortable with the responsibility. The babysitter is the counterpart of the designated driver in situations that do not involve driving. In some cases, the babysitter does not drink at all; in other cases, the babysitter is simply the most sober person at the end of the night. One student called the babysitter a "sensible drunk" who gives students confidence that they will be safe.

Both the safety net of the group and the use of babysitters can effectively provide some level of safety; however, two problems are permission has been granted for this version to appear in e-Publications@ Marquette. Routledge (M.E. Sharpe) does not grant permission for this article to be further copied/distributed or hosted elsewhere without the express permission from Routledge (M.E. Sharpe). 
evident, either of which can increase the level of risk to others. One is that not all babysitters are competent. The other is that, though babysitters and groups are able to provide some measure of safety, they can also provide a false sense of security that facilitates heavier drinking. Students who drink in groups with babysitters may feel that the burden of responsibility is lifted and that they can safely engage in binge drinking. Some researchers have concluded that if students felt personally responsible for their own safety, they would not drink as heavily (Knight, Glascoff, and Rikard 1993). One student acknowledged this belief.

Many situations result because students regularly make riskier decisions when they are among a large group of the peers. Individuals are more likely to behave in ways that they would not if they were alone, which makes it increasingly more dangerous for a student who has been consuming large quantities of alcohol to be influenced by peers to partake in risky situations (student \#8).

Designating a Driver. The second-most common strategy of risk management is to designate a driver when students are attending parties or going to bars beyond walking distance from campus. According to student \#9, "Drinking and driving is such a big issue ... it has become much more routine for a group to designate a driver before going out." Despite the level of reassurance that designating a driver provides, problems can occur. A common situation occurs when the student drives alone to a bar and, at the end of the night, does not want to leave the car and take a cab.

They think, "I'll only have a few drinks and will be OK to drive." Many times a few drinks turns into many, and the person drives home drunk (student \#53).

Other problems arise when the designated driver does not stay sober but simply stops drinking a little earlier than the group; however, a more serious problem can occur when the designated driver is chosen on the basis of driving ability while intoxicated. These drivers are often far over the legal limit after a night of drinking but are chosen because they have successfully driven drunk before without getting caught. 
NOT THE PUBLISHED VERSION; this is the author's final, peer-reviewed manuscript. The published version may be accessed by following the link in the citation at the bottom of the page.

Drinking Defensively, Avoiding Risky Situations, Walking Away from Trouble. Taking steps to avoid risks while drinking is a strategy that some students adopt, if they are sober enough to exercise that judgment.

If students can clearly think and are aware of what is happening, they will not consciously put themselves in a dangerous situation. However, many times a person is too drunk to know or understand the risks that are out there (student \#29).

Walking away from trouble is especially true with regard to fights. Several students recognized the possibility of fights breaking out, and they resolved to avoid them rather than to be part of a brawl. Said student \#26, "I think that we use our intuition and if we feel uncomfortable at a party ... we'll leave."

Other defensive drinking suggestions included (1) holding your own drink at all times and getting refills yourself to avoid someone putting a date rape drug in it, (2) "crashing" at a friend's house, (3) carrying a buzzer or defense spray to have some sort of protection, and (4) carrying a cell phone with a cab company telephone number already programmed into it.

Pacing Yourself, Knowing Your Limits. Some students drink defensively, as noted previously, but do not moderate their drinking. Others refrain from drinking excessively because they have learned from experience that there are limits to what they can drink.

Depending on the amount of self-efficacy they possess and the type of negative consequences they have experienced in the past (embarrassment, disgust, illness, or injury), they may resolve to alter their behavior in the future and learn to pace themselves.

Most of us know when to control one's alcohol content; however, we run into situations when people have to baby-sit friends when they make the mistake of going overboard, or even worse, when you yourself get out of control. ... There are times when I drink, but trust me. I have learned from a past experience that helps me avoid consuming large amounts of alcohol (student \#10).

Journal of Advertising, Vol 30, No. 4 (Winter 2001): pg. 23-39. DOI. This article is (C) Routledge (M.E. Sharpe) and permission has been granted for this version to appear in e-Publications@Marquette. Routledge (M.E. Sharpe) does not grant permission for this article to be further copied/distributed or hosted elsewhere without the express permission from Routledge (M.E. Sharpe). 
Of these five strategies-taking chances, drinking with friends, designating a driver, drinking defensively, and pacing yourself-only the last truly minimizes risk by reducing consumption. The others take excessive drinking as a given and either do nothing to minimize risk or simply try to impose some controls within the environment. Most participants did not see the need for more restrictive measures. It appears that when students feel invincible and have successfully beat the odds against consequences in previous drinking episodes, they are convinced that there is no need to curb their drinking.

\section{Self-Efficacy}

According to the risk models, those who feel vulnerable and perceive severe threats must be capable of taking action to control the dangers of binge drinking. Otherwise, they may simply control the fear through denial or other inappropriate actions. Self-efficacy, or the ability to take action, is addressed in RQ5 (What insights do they reveal regarding their ability to enact behaviors that can minimize risk associated with binge drinking?). Of the behaviors noted as ways to manage risk, several require no real consideration of self-efficacy. Taking chances does not necessitate any specific behavior that would require self-efficacy, nor does drinking with friends, because it is motivated by socialization instead of by risk management.

Selecting a babysitter and designating a driver are two behaviors that assign responsibility to others, which also negates the need for self-efficacy, beyond the ability to carry out the selection process. Once responsibility is placed on someone else, the need for self-efficacy is diminished. In contrast, being a designated driver or babysitter can require considerable self-efficacy in handling responsibility, though many students are not aware of this until confronted with a potentially dangerous situation. This is illustrated by a student's account of an incident in which he was too drunk to think clearly in an emergency. His friend fell three stories trying to enter a locked apartment from a window, breaking his $\mathrm{mm}$ and "gash[ing] his head open." The injured student recovered, but the student in charge was too "freaked out" to know what to do. 
NOT THE PUBLISHED VERSION; this is the author's final, peer-reviewed manuscript. The published version may be accessed by following the link in the citation at the bottom of the page.

Since I was kinda drink too, I was like "oh my gosh" ... and I was freaking out .... I told my friends what happened and I asked like should we call the cops? ... I don't know, and I was so out of it that I didn't know if we should call the cops or not. Even though any normal person would be like, "yes, call the cops," but I didn't know what to do (student \#52).

The difficulties of making good decisions also occur in social settings, in which incidents that appear harmless can quickly become serious.

Many people go to parties in groups and ask their friends to make sure they "don't kiss Rob" or make sure they "make it home safe." However, students forget that their friends are drinking too and are not making good decisions either. So by the time a girl is assaulted, it is too late for her friends to stop it because they just thought it was funny that she was kissing Rob again (student \#10).

Knowing to avoid risky situations, having the presence of mind to walk away from trouble, and pacing yourself are the forms of risk management that require high levels of judgment and self-efficacy. However, alcohol consumption itself diminishes many students' ability to take responsible action, as noted in the previous two students' comments. Otherwise, the most difficult challenges to self-efficacy are handling peer pressure and developing refusal skills, which appear to be affected by age and maturity. Many students are caught in situations in which they do not want to drink but fear rejection and worry that they will be made to feel different if they do not take part. Their desire to fit in is great, and their refusal skills are inadequate. The following two factors appear to affect self-efficacy for enacting refusals.

Vulnerability to Peer Pressure. Participants were unanimous in their comments that freshmen are the most "at-risk" group in their ability to stand up to peer pressure. The first year is the hardest, because students are dealing with unfamiliar surroundings, the need to fit in, little physical tolerance for alcohol, and, in some cases, little prior experience with alcohol.

Journal of Advertising, Vol 30, No. 4 (Winter 2001): pg. 23-39. DOI. This article is (C) Routledge (M.E. Sharpe) and permission has been granted for this version to appear in e-Publications@Marquette. Routledge (M.E. Sharpe) does not grant permission for this article to be further copied/distributed or hosted elsewhere without the express permission from Routledge (M.E. Sharpe). 
NOT THE PUBLISHED VERSION; this is the author's final, peer-reviewed manuscript. The published version may be accessed by following the link in the citation at the bottom of the page.

[Freshmen] have just come from an environment where they know everything and have a very solid group of friends [during high school]. They are thrust into a new city with all new people and a very difficult course load .... Alcohol makes it easier to meet new people because it reduces your inhibitions (student \#24).

Changes Due to Age. Some students drink more when they turn 21 years of age because the legal barrier is lifted. This is particularly true of those who believed that underage drinking was too risky and chose not to drink much prior to turning 21 . Among those who were heavy underage drinkers, however, it appears that many decrease their drinking as they get older because they drink with a more mature focus and are less susceptible to peer pressure.

I have many friends who are over 21 and they drink a lot, but they rarely drink in excess. I attribute this to the fact that they can drink anytime and they realize this. The need to "get totally wasted right now" dissipates (student \#35).

One student who gained some perspective commented, "I hope as we get older that more people my age start to realize that drinking isn't as uplifting an activity as they once thought" (student \#13).

\section{Ritual Influence}

The study also addresses RQ6 (Do the three ritual functionscommunity, order, and transformation provide benefits from binge drinking that may need to be balanced against other factors?). Students' comments suggest that the benefits of each of the three ritual functions are too great to sacrifice.

Community. Students who drink to fit in find that gaining a community of friends makes the risk of drinking acceptable. Alcohol consumption creates an instant way of connecting with people and finding social acceptance.

When you get to college, you realize that alcohol is the one thing that you probably have in common with all these strangers around you. It almost makes sense to drink-aside from the fact that it is illegal ... and dangerous (student \#42).

Journal of Advertising, Vol 30, No. 4 (Winter 2001): pg. 23-39. DOI. This article is (C) Routledge (M.E. Sharpe) and permission has been granted for this version to appear in e-Publications@Marquette. Routledge (M.E. Sharpe) does not grant permission for this article to be further copied/distributed or hosted elsewhere without the express permission from Routledge (M.E. Sharpe). 
This comment shows some weighing of costs and benefits from drinking but strongly implies that the common bond with other students offsets the risks from an "illegal" and "dangerous" activity. The second comment shows that being rejected socially is a greater risk than any dangers from consumption itself.

When I am sober, I often feel that there is a risk in speaking and talking with women. There is the risk of being rejected. However, when I am intoxicated, that risk seems to be null and void (student \#7).

Order. The second ritual function is the need for order. Rules, whether stated explicitly or implicitly, exist in all types of ritual interaction with others; however, students experience more uncertainty in social situations when they are sober. Students who follow the rules of drinking believe they are almost guaranteed to fit in. Rules also guide participants on such matters as when, where, and how much to drink, as well as what to say.

Some start to drink right after the last class on Friday. You go to lunch at noon and have about 6 beers, go back home, have some more from about 3 p.m. 'till 5 p.m. Then your friends come over and you keep drinking until 10 p.m. Then you go to a bar or party ... when someone asks you what you did the night before, you just say "I can't remember" (student \#35).

Other behaviors that order how much to drink include both the playing of drinking games, which vary somewhat from group to group but typically impose rules for drinking that result in heavy consumption, and "pre-gaming," or drinking at home before going out to save money or get a head start on getting drunk.

Transformation. The third and final ritual function is the need for transformation. Many participants spoke of the extreme stress they experienced as students and the desire they have to relax-the "work hard, party hard" ethic. Students under stress often turn to alcohol as a way of numbing the pain, becoming a different person, and escaping from reality. Whereas the first comment reveals a moderate amount of stress, the second speaks of an extreme amount. 
NOT THE PUBLISHED VERSION; this is the author's final, peer-reviewed manuscript. The published version may be accessed by following the link in the citation at the bottom of the page.

After working hard at their jobs and classes all week long, most college students are looking for ways to relax on the weekends. After getting moderately drunk, they feel as if they can relax with their friends, possibly meet some new friends, and just have fun (student \#9).

As college students we face the possibility of having a nervous breakdown. There is so much stress involved in college life that some students get to the point where they feel overwhelmed. Students may have three papers due in one week on top of two to three exams. Plus, as college students we have to worry about finances and our jobs. We have to go to class and squeeze in time to do our papers, we have extracurricular activities to worry about, and relationships. We have all these stresses, very little time, little sleep, and these factors can lead us to the brink of destruction (student \#15).

Sometimes the transformation takes a different form than gaining freedom from responsibilities and relieving stress. In these cases, the transformation enables students to become a different person, one who is socially more adept or more adult. The goal of getting drunk and being transformed offsets the concerns of risk.

Students like to drink because they open up, and it lets them unwind after a stressful week. Plus it offers a good social setting. But students ... do it with the intent to get drunk. They want to get smashed, party, or get messed up. Drinking itself is a risky issue but people, guys and girls alike, have an agenda when they drink: to get drunk, party, or get some action (student \#4).

Each function offers benefits that can make the risks of drinking acceptable, but taken collectively, these three may offer compelling incentives to take chances.

\section{Other Attitudes and Beliefs that Support Ritual}

\section{Functions}

At this point, the study addresses RQ7 (Do students exhibit other attitudes or beliefs relevant to costs and benefits?). The following six attitudes explicitly reflect some weighing of the consequences against the benefits of drinking, and on closer

Journal of Advertising, Vol 30, No. 4 (Winter 2001): pg. 23-39. DOI. This article is (C) Routledge (M.E. Sharpe) and permission has been granted for this version to appear in e-Publications@Marquette. Routledge (M.E. Sharpe) does not grant permission for this article to be further copied/distributed or hosted elsewhere without the express permission from Routledge (M.E. Sharpe). 
examination, all are extensions of the ritual functions. The benefits reflected in these beliefs appear to be so strong that they can successfully compete against motives to drink less, making the cost of moderation or abstinence too high for some students. They may also be used as justifications to drink, especially for those who lack the self-efficacy to control the danger and must control the fear instead.

Drinking Makes for Great Stories and Offers the Best Memories of College Life. An extension of the community function is the storytelling that occurs after drinking. Many students acknowledged that binge drinking has risks, but the great memories and stories are worth it. In this sense, the benefits of drinking are not merely experienced at the moment, but the day after, the week after, and even years after. Drinking stories are usually told when sober and are a way of reliving the moment and bonding with others.

All these things carry some degree of risk but they are also the things that I will remember when I look back on my college career. I regret none of the things that I have done related to drinking, and I'm sure none of my friends do either. It's funny and gives us something to talk about the rest of the week (student \# 32).

As a freshman, I constantly walked to parties by myself completely wasted. I would drink from random cups, stumble home and think it was hilarious. Looking back now, I still don't think that I was really in any danger. Maybe I was, but I don't think that I would have done much differently, even looking back on the situations a year later, completely sober. They just make too good stories and are too much fun (student \#46).

We Have the Freedom to Drink. Two attitudes that are extensions of the ordering function relate to the timing of the college years for drinking. Most students are enjoying the freedom to make their own decisions for the first time. The newfound freedom provides a powerful motivation to experiment with alcohol, because it was previously forbidden for most students.

Students are in college now, and this is their time to come out and be who they weren't allowed to be in high school living under their parents' roof (student \#35). 
NOT THE PUBLISHED VERSION; this is the author's final, peer-reviewed manuscript. The published version may be accessed by following the link in the citation at the bottom of the page.

They take the risk because there is no authority to stop them. They don't have to face their parents in the morning if they are sick (student \#26).

College Is the Best Time in our Lives for Drinking, Perhaps the Only Time We Can Afford to Drink Heavily. Students also voiced the feeling that there is no better time in their life to drink. During high school, authority figures restrict access to alcohol. After graduation from college, responsibilities of jobs get in the way. College is really the only time they are free to drink with impunity.

You don't have responsibilities. You have responsibilities to school, but it's not life threatening. With your job, if you go out drinking every night and you slack off like a week, you're fired. And that's your life. That is your livelihood. With college, if you slack off for a week, you're going to get bad grades, and you can make it up. Also, in college you don't get a bad image for going out every night. If teachers went out and got plastered and came in hungover every day, they'd set a bad example. With us, we can go to class hungover as anything and no one really cares (student \#52).

Nothing Else Compares with the Sensation or Thrill of Alcohol. Three attitudes relate to the transformation function. The first offers escapism through thrill-seeking behavior. Students believe that risk taking brings a rush of adrenalin that can not be achieved by other activities. The element of risk is one of the things that makes drinking meaningful to them.

In a setting with friends and no parents, it is exciting and thrilling to try to do things you shouldn't be doing. When an underage person gets into a bar for the first time, the feeling is a rush-you can get unlimited drinks, there are older people around, and there are other sorts of entertainment that you just don't get from hanging out at a friend's dorm room Saturday night (student \#51).

Drinking Allows Us to Live Life to the Fullest. Also related to sensation seeking is the desire to live life without regrets. Ironically, students believe they would experience deeper regrets for not drinking (and therefore not living life to the fullest) than they would for any of the consequences of drinking. Participants voiced the belief that if they

Journal of Advertising, Vol 30, No. 4 (Winter 2001): pg. 23-39. DOI. This article is (C) Routledge (M.E. Sharpe) and permission has been granted for this version to appear in e-Publications@ Marquette. Routledge (M.E. Sharpe) does not grant permission for this article to be further copied/distributed or hosted elsewhere without the express permission from Routledge (M.E. Sharpe). 
held back and lived cautiously, they might miss something important that they would regret later.

It's the things that we don't do in life that we later regret. There is something in us that wants to ... drink every last drop of the short amount of time that we have here. We don't want to be looking up to the sky thinking . . . that we gypped ourselves out of what could have been an extraordinary life. And if leading that extraordinary life means putting parts of us on the line, then we feel that it is a small price to pay ... our list of "dids" will be bigger than our list of "should haves" (student \#9).

Alcohol Excuses "Bad Behavior." The third extension of the transformation function shares commonalities with the order function. It is reflected in the belief that alcohol magically changes the rules of conduct. Drinking allows students to change from young adults with strong moral codes that forbid immoral or "bad behavior" into young adults who act without inhibition. Those who feel that the rules of conduct are too restrictive while sober find freedom when intoxicated. Most believe that they can get away with "bad behavior" while intoxicated and will not be held responsible for acts performed while drinking, thus, the common excuse, "I was so wasted."

Drinking is a good way for kids to make excuses for something they really wanted to happen. For example, a guy can give a girl a few drinks and say he just wanted to relax, chat and have a good time, when his real motive is to get her drunk and vulnerable (student \#24).

Some students regarded this excuse as manipulative and invalid, though it is a commonly offered excuse.

I know a girl who always lifts up her dress when she's drinking. I think she's an exhibitionist, and she really doesn't care what she's doing. She just pretends to care afterwards-like "I did that? Oh my gosh, I was so drunk." She's just using that as an excuse because it's what she wants to do (student \#52). 
NOT THE PUBLISHED VERSION; this is the author's final, peer-reviewed manuscript. The published version may be accessed by following the link in the citation at the bottom of the page.

\section{Conclusions}

\section{Summary of Findings}

This study addresses six topic areas related to the risks of binge drinking among college students: perception of risks and their severity, vulnerability to risks, management of risks, ability to enact behaviors that minimize risk, ritual benefits of binge drinking, and the influence of other attitudes and beliefs. Although 13 potentially hazardous risks were identified, students rarely perceive them as severe, nor do most feel personally vulnerable. Many students do little to consciously avoid risks, because they believe they are safe. The primary management of risk is to take chances; however, other behaviors that increase actual safety or the perception of safety include drinking with friends and designating a driver or babysitter. Some techniques for managing risk require considerable self-efficacy, such as pacing yourself, whereas others require very little. Benefits from ritual functions are strong, which enter into the weighing of costs and benefits of drinking. Table 1 offers a summary of all findings.

\section{Limitations}

Because these data are from a qualitative study of a single campus, it cannot claim or guarantee generalization. However, because many of the findings have been reported in other studies with the same results, there is no reason to believe the findings would not extend beyond the campus under investigation. Findings supported in other studies include the ritual functions of drinking (Treise, Wolburg, and Otnes 1999) students' misperception of vulnerability (Weinstein 1987), the perception of a protected environment (Dorsey, Scherer, and Real 1999), the ineffectiveness of designated drivers (DeJong and Wallack 1992; Seal 1990), the role of drinking games (Clapp, Shillington, and Segars 2000), and the influence of social networks (Dorsey, Scherer, and Real 1999).

This study uses the accepted definition of binge drinking as the standard for problem drinking; however, the limitations of this definition have already been noted. It would be fruitful to consider whether the problem that should be addressed in further research is permission has been granted for this version to appear in e-Publications@Marquette. Routledge (M.E. Sharpe) does not grant permission for this article to be further copied/distributed or hosted elsewhere without the express permission from Routledge (M.E. Sharpe). 
NOT THE PUBLISHED VERSION; this is the author's final, peer-reviewed manuscript. The published version may be accessed by following the link in the citation at the bottom of the page.

consumption per se, level of impairment when drinking, or simply drinking associated with negative outcomes.

\section{A Return to Risk Models}

All of the concepts identified in the risk models received support in this data set, which speaks well of their explanatory power. However, no one model accounted for all the concepts. The PMT and the EPPM both focus on processes and relationships among elements, both of which are missing in the HBM. The PMT assumes a cognitive response and ignores the emotionally based, fear-control response addressed by the EPPM. The EPPM accounts for both cognitive and emotional processing of information but ignores the weighing of costs and benefits. The Integrated Risk Perception Model (IRPM) is offered to combine the existing models in a manner that accounts for all concepts and provide the best fit to the qualitative data in this study (see Figure 1). Although the two processes (danger control and fear control) are only inferred, the concepts of threat, vulnerability, response efficacy, self-efficacy, and costs versus benefits clearly emerge in the data.

\section{Three Conditions in the IRPM}

The IRPM provides an understanding of the conditions that are most likely to lead to adaptive changes in behavior, which can provide further insights for PSA development. Previous research suggests that students who do not recognize the risks associated with drinking and/or do not feel personally vulnerable to those risks will not modify their drinking behavior (Condition 1). They have no motivation to change; thus, any consideration of efficacy or relative costs and benefits is irrelevant. When these students are exposed to PSAs that encourage behavior modification on the basis of risk, the message is likely to be disregarded.

Students who recognize the risks associated with drinking and feel personally vulnerable are better candidates for behavior modification, but only if they feel that the benefits of the adaptive behavior, such as drinking less or abstaining, outweigh the costs, which are essentially the loss of benefits from drinking (Condition 2). Those who believe that the costs outweigh the benefits (Condition 3) 
know that they could suffer serious consequences as a result of drinking, but they are unwilling to pay the costs. The benefits of drinking, such as fitting in, being socially accepted, or relieving stress, are simply too great to give up. For these students, response efficacy and self-efficacy become irrelevant concepts. When they are exposed to PSAs with risk messages, the belief that they are engaging in risky behavior most likely leads to fear, which typically triggers a defensive reaction such as denial or other maladaptive changes. In extreme cases, students will do the opposite of what is advocated, namely, drink more excessively.

Students in Condition 2 who recognize the risks, feel personally vulnerable, and believe that the benefits of adaptive behavior outweigh the costs must then address efficacy before deciding on a course of action. When response efficacy and self-efficacy are low, the same fear response is expected as in Condition 3; however, when efficacy is high, the most likely response is protection motivation. When exposed to a PSA with a risk message, these students are the most likely to try to control the danger rather than the fear. They are the best candidates for enacting adaptive changes.

\section{Recommendations for PSAs}

Risk messages are not the only strategy open to creators of PSAs, but they are an important one for the right audience. Those in Condition 2 who engage in protection motivation appear to be the best candidates for behavior modification, whether it occurs as a result of exposure to a risk message or their own personal experience; however, these students are probably a minority of the total audience. A wide variety of risk messages, including ones that simply reinforce vulnerability and the nature of the threat, may be sufficient to lead to positive action, because this audience is capable of carrying out the action and does not have much to lose by giving up the risky behavior. Simple messages noted previously, including "You drink and drive. You lose," "Friends don't let friends drive drunk," and the series of ads showing footage of babies who later died as a result of drunk driving accidents, may be very effective in motivating these people to control the danger. Efficacy messages, such as those recommended next, should also be effective.

Journal of Advertising, Vol 30, No. 4 (Winter 2001): pg. 23-39. DOI. This article is (C) Routledge (M.E. Sharpe) and permission has been granted for this version to appear in e-Publications@Marquette. Routledge (M.E. Sharpe) does not grant permission for this article to be further copied/distributed or hosted elsewhere without the express permission from Routledge (M.E. Sharpe). 
Those in Condition 2 who engage in fear control due to a lack of efficacy are likely to be fearful of risk messages and engage in denial. For this audience, the best tactic for PSAs might be to avoid focusing on the threat and instead increase efficacy in hopes that audience members can shift to a danger-control response. Messages could reinforce the efficacy of the response that is promoted, for example, by informing people that, when drinkers consume one fewer drink, traffic fatalities, accidents, rapes, and vandalism decrease. In such cases, actual statistics would be needed. Messages could build selfefficacy through teaching refusal skills for situations in which peer pressure is high, just as anti-smoking ads have done (Pechmann et al. 2001). Messages that show detailed enactments of refusals in realistic settings are recommended, unlike the "just say no" campaign, which was criticized by some for oversimplifying the act of refusal (Kalb 200 1).

Other messages that ask for relatively small levels of selfefficacy could focus on the risk management tactics described by participants in the study, such as not letting go of your drink, programming a cell phone to dial a cab, staying overnight with a friend, walking away from fights, and generally learning to drink defensively. Because some students already utilize these tactics, other students may willingly adopt them. These small changes in behavior may build confidence in self-efficacy and effectively reduce some of the risks.

Encouraging students to drink with friends and designate a driver are similar self-efficacy strategies that have already been heavily promoted, but few messages are detailed about how the behavior should be enacted. Greater efficacy might be achieved if the messages were more explicit about how many (if any) drinks are appropriate for the designated driver. Messages could also teach students how to designate a driver, for example, doing so prior to drinking rather than waiting until the end of the evening. Without a prior decision, the designated driver may simply be any person who believes he or she can drive under the influence without getting caught. In addition, PSAs could teach people to take turns as the designated driver based on what is effective for the group. In many permission has been granted for this version to appear in e-Publications@Marquette. Routledge (M.E. Sharpe) does not grant permission for this article to be further copied/distributed or hosted elsewhere without the express permission from Routledge (M.E. Sharpe). 
cases, the designated driver is the person who has the heaviest demands the next day because such demands often dictate staying sober the night before.

Other messages might address safety decisions in groups that do not explicitly designate a driver or babysitter. These messages might show a person deciding to consume less if he or she sees that others are drinking so heavily that they may be unable to get home safely. However, to counter the tendency for some group members to shift too much responsibility to the designated driver or babysitter, messages should remind other students that designating a driver does not also mean designating all responsibility.

For students in Condition 1, who feel 'bulletproof' and do not regard drinking as risky, other strategies may be needed that are not based on risk. Some attempts to change attitudes have been made successfully with social norm approaches, which assume that people will change their behavior to adhere to what they perceive as the norm. Perkins and Berkowitz (1986) discovered that students usually overestimate campus drinking norms, with recent estimates of binge drinkers as high as $70 \%$ of students compared with the actual rate of $44 \%$ nationally. Some interventions have brought about a declining rate of binge drinking simply when these misperceptions are corrected; however, the effectiveness of such interventions are believed to be limited to campuses at which the actual binge drinking rate is less than soc1c (Haines 1996). Social norm approaches have typically addressed misperceptions of the prevalence of binge drinking, but they could easily challenge other incorrect beliefs, depending on specific characteristics of a particular campus. For example, when actual numbers are known, a message could counter the belief that everyone takes chances by noting how many people take precautions.

In hopes of increasing the awareness of threat and feelings of vulnerability among the students in Condition 1, it may be useful to challenge the incorrect beliefs about risk noted in this study. For example, a message could address the mistaken belief that students are safe as long as they drink with friends. A PSA could state how many accidents, deaths, rapes, and so forth actually happen under the watchful eyes of friends. A voiceover or spokesperson approach with permission has been granted for this version to appear in e-Publications@ Marquette. Routledge (M.E. Sharpe) does not grant permission for this article to be further copied/distributed or hosted elsewhere without the express permission from Routledge (M.E. Sharpe). 
statistical evidence is one tactic, and another is the use of testimonials. This technique is recommended because previous research has found that testimonials are more persuasive and remembered longer than is statistical evidence (Kazoleas 1993). Members of two potential groups would appear to be the most appropriate choices: other college students (or models who appear to be students) or celebrities who are popular role models. Testimonials could effectively challenge or discredit attitudes that facilitate drinking by communicating that students are not invincible, that drinking with friends does not always ensure safety, that college is not always a protected environment, that not everyone believes that "I was so wasted" excuses bad behavior, that not everyone drinks, and so forth.

One final recommendation is the need to respect the ritual functions. Treise, Wolburg, and Otnes (1999) recognize that decreasing consumption offers a new set of risks, including the loss of a community of friends, the loss of order and security, and the loss of escapism and other forms of transformation. By understanding the need to fulfill ritual functions, PSA developers should attempt to craft messages that work with the ritual functions rather than against them. Treise, Wolburg, and Otnes (1999) developed three messages as examples that show how these themes can be developed, one of which offers a new social role in "Be a real drinking buddy." It inverts the "drinking buddy" term and suggests that a true friend is not someone who promotes consumption. Campus interventions and PSAs should have better chances for success if they offer ways to replace ritual benefits rather than expect students simply to forgo them. For example, some schools offer activities during the hours in which students would otherwise be drinking. This maintains the order function. Although the task of replacing ritual functions is challengingdrinking can offer students multiple benefits that are difficult to replace-it may not be insurmountable.

These recommendations suggest a variety of strategies for targeting students on the basis of their differing needs and perceptions. The specific messages appear to complement one another and could be used jointly in hopes that one or more would effectively target each student. Collectively, these approaches should resonate with students because they emerged from students themselves. 
NOT THE PUBLISHED VERSION; this is the author's final, peer-reviewed manuscript. The published version may be accessed by following the link in the citation at the bottom of the page.

\section{References}

Abbey, Antonia, L.T. Ross, D. McDuffie, and Pam McAuslan (1996), "Alcohol and Dating Risk Factors for Sexual Assault among College Women," Psychology of Women Quarterly, 20 (1), 147-169.

Ad Council Campaigns (2001), www.adcouncil.org (April 19, 2001).

Bandura, Albert (1977), Social Learning Theory, Englewood Cliffs, NJ: Prentice Hall. (1986), Social Foundation of Thought and Action, Englewood Cliffs, NJ: Prentice Hall.

Becker, Marshall H. (1974), "The Health Belief Model and Personal Health Behavior," Health Education Monographs, 2 (4), 324-4 73.

Binge Drinking Blows Campaign (2001), www.cspinet.org; booze/hadenough/index1.htm (April 19, 2001)

Clapp, John D., Audrey Shillington, and Lance B. Segars (2000), "Deconstructing Contexts of Binge Drinking Among College Students," American Journal of Drug and Alcohol Abuse, 26 (1), 139-154.

DeJong, William and Lawrence Wallack (1992), "The Role of Designated Driver Programs in the Prevention of Alcohol-Impaired Driving: A Critical Reassessment," Health Education Quarterly, 19 (4), 429-442.

Dorsey, Alicia M., Clifford W. Scherer, and Kevin Real (1999), "The College Tradition of 'Drink 'Til You Drop': The Relation Between Students' Social Networks and Engaging in Risky Behaviors," Health Communication, 11 (4), 313-334.

Driver, Tom. (1991), The Magic of Ritual, New York: HarperCollins.

Glaser, Barney G. and Anslem L. Strauss (1967), The Discovery of Grounded Theory: Strategies for Qualitative Research, Chicago: Aldine.

Gotthoffer, Alyse and Kent Lancaster (200 1), "Estimating the Audience Coverage of PSAs: The Ad Council's Drunk Driving Prevention Campaign," Journal of Advertising Research, 41 (5), in press.

Had Enough Campaign (2001), "Sobering Statistics," www.cspinet.org/booze/hadenough/campuslife/studentstories.html (April 19, 2001).

Haines, Michael P. (1996), "A Social Norms Approach to Preventing Binge Drinking at Colleges and Universities," in Higher Education Center for Alcohol and Other Drug Prevention, Washington, DC: U.S. Department of Education, 1-23.

Jacobs, James B. (1989), Drunk Driving: An American Dilemma, Chicago: The University of Chicago Press.

Janz, N.K. and Marshall H. Becker (1984), 'The Health Belief Model: A Decade Later," Health Education Quarterly, 11 (1), 1-47.

Kalb, Claudia (2001), "DARE Checks into Rehab," Newsweek, 137 (9), 56.

Journal of Advertising, Vol 30, No. 4 (Winter 2001): pg. 23-39. DOI. This article is (C) Routledge (M.E. Sharpe) and permission has been granted for this version to appear in e-Publications@Marquette. Routledge (M.E. Sharpe) does not grant permission for this article to be further copied/distributed or hosted elsewhere without the express permission from Routledge (M.E. Sharpe). 
NOT THE PUBLISHED VERSION; this is the author's final, peer-reviewed manuscript. The published version may be accessed by following the link in the citation at the bottom of the page.

Kazoleas, D. C. (1993), "A Comparison of the Persuasive Effectiveness of Qualitative Versus Quantitative Evidence: A Test of Explanatory Hypotheses," Communication Quarterly, 41 (1), 40-50.

Knight, Sharon, Mary Glascoff, and G. Linda Rikard (1993), "On Being a Designated Driver: A Qualitative Investigation of Underage College Student Perceptions," Journal of College Student Development, 34 (6), 425-431.

Leventhal, Howard (1970), "Findings and Theory in the Study of Fear Communications," Advances in Experimental Social Psychology, Vol. 5, L. Berkvwitz, ed., New York: Academic Press.

Lindlof, Thomas R. (1995), Qualitative Communication Research Methods, Newbury Park, CA: Sage Publications.

Maddux, J.E. and Ronald W. Rogers ( 1983J, "Protection Motivation and SelfEfficacy: A Revised Theory of Fear Appeals and Attitude Change," Journal of Experimental Social Psychology, 19 (5), 469-479.

Marcus, David L. (2000), "Drinking to Get Drunk: Campuses Still Can't Purge Binging Behavior," U.S. News \& World Report, 128 (12), 53-54.

McCracken, Grant (1988), The Long Interview, Newbury Park, CA: Sage Publications.

Mendelson, Eric (2000), "Emphasis on Social Norms Can Help Curb Drinking," The Chronicle of Higher Education, 47 (8), B13-B14.

Morgan, David L. (1988), Focus Groups as Qualitative Research, Newbury Park, CA: Sage Publications.

National Highway Traffic Safety Administration (2001), "Traffic Safety Facts 2000," U.S. Department of Transportation, www.nhtsa.dot.gov (October 11, 2001).

O'Sullivan, Sean (2001), "Drinking Habits Die Hard at University of Delaware," www.delawareonline.com/newsjournal/local/2001/05/29drink.html (May 30, 2001).

Pechmann, Connie, Marvin E. Goldberg, Ellen Thomas Reibling, and Guangzhi Zhao (2001), "What to Convey in Antismoking Ads for Adolescents? The Use of Protection Motivation Theory to Identify Effective Message Themes," working paper, University of California, Irvine.

Perkins, H. Wesley and Alan D. Berkowitz (1986), "Perceiving the Community Norms of Alcohol Use Among Students: Some Research Implications for Campus Alcohol Education Programming," International Journal of the Addictions, 21 (9), 961-976.

Presley, Cheryl A, Philip W. Meilman, and Rob Lyerla (1993), Alcohol and Drugs on American College Campuses: Use, Consequence, and Perceptions of The Campus Environment, Vol. 1, Carbondale, IL: The Core Institute.

Journal of Advertising, Vol 30, No. 4 (Winter 2001): pg. 23-39. DOI. This article is (C) Routledge (M.E. Sharpe) and permission has been granted for this version to appear in e-Publications@Marquette. Routledge (M.E. Sharpe) does not grant permission for this article to be further copied/distributed or hosted elsewhere without the express permission from Routledge (M.E. Sharpe). 
NOT THE PUBLISHED VERSION; this is the author's final, peer-reviewed manuscript. The published version may be

accessed by following the link in the citation at the bottom of the page.

Roan, Shari (2001), "Car Deaths Related to Alcohol Increase," Los Angeles Times (October 1), www.hecnews@phoenix.edc.org (October 10, 2001).

Roberto, Anthony J., Gary Meyer, Amy Janan Johnson, and Charles K. Atkin (2000), "Using the Extended Parallel Process Model to Prevent Firearm Injury and Death: Field Experiment Results of a Video-Based Intervention," Journal of Communication, 50 (3), 157-175.

Rogers, Ronald W. (1975), "A Protection Motivation Theory of Fear Appeals and Attitude Change," Journal of Psychology, 91 (1), 93-114.

-----, ( 1983), "Cognitive and Physiological Processes in Fear Appeals and Attitude Change: A Revised Theory of Protection Motivation," in Social Psychophysiology, John Cacioppo and Richard Petty, eds., New York: Guilford, 153-176.

Rook, Dennis W. (1985), "The Ritual Dimension of Consumer Behavior," Journal of Consumer Research, 12 (December), 252-264.

Rose, H. L. (1991), "If It Feels Good, It Must Be Bad," Fortune, 91 (2), 96105.

Rosenstock, Irwin M. (1991), "The Health Belief Model: Explaining Health Behavior Through Expectancies," in Health Behavior and Health Education: Theory, Research, and Practice, K. Glanz, F.M. Lewis, and B.K. Rimer, eds., San Francisco: Josey-Bass Publishers, 39-62.

Schneider, D. and J. Morris (1991), "Risk-Taking Behaviors of College Students," Environment and Behavior, 23 (5), 575-591.

Seal, A.B. (1990), "Designated Driver Programs: Time to Rethink," Adolescent Counselor, (April;May), 43-45.

Simon, Toby (1993), "Sexuality on Campus-'90s Style," Change, 25 (3), 50. Taylor, Ronald E. : 1994J, "Qualitative Research," in Mass Communication Research, Michael W. Singletary, ed., New York: Longman, 265-279.

Think When You Drink Campaign t2001J, www.millerbrewing.com (April 19, 2001).

Treise, Debbie, Joyce M. Wolburg, and Cele Otnes (19991, "Understanding the 'Social Gifts' of Drinking Rituals: An Alternative Framework for PSA Developers," Journal of Advertising, 28 (12), 17-32.

We All Make a Difference Campaign (2001), www.Budweiser.com (April 19, 2001).

Wechsler, Henry, Kathleen Kelley, Elissa R. Weitzman, John Paul San Giovanni, and Mark Seibring (2000), "What Colleges Are Doing About Student Binge Drinking: A Survey of College Administrators," Journal of American College Health, 48 (5), 219-226.

-----, Barbara Moeykens, Andrea Davenport, Sonia Castillo, and J. Hansen (1995), "The Adverse Impact of Heavy Episodic Drinkers on Other College Students," Journal of Studies on Alcohol, 56 (6), 628-634.

Journal of Advertising, Vol 30, No. 4 (Winter 2001): pg. 23-39. DOI. This article is (C) Routledge (M.E. Sharpe) and permission has been granted for this version to appear in e-Publications@Marquette. Routledge (M.E. Sharpe) does not grant permission for this article to be further copied/distributed or hosted elsewhere without the express permission from Routledge (M.E. Sharpe). 
NOT THE PUBLISHED VERSION; this is the author's final, peer-reviewed manuscript. The published version may be accessed by following the link in the citation at the bottom of the page.

Weinstein, N.D. (1987), "Unrealistic Optimism about Susceptibility to Health Problems: Conclusions from a Community-wide Sample," Journal of Behavioral Medicine, 10 (5), 481-500.

West, G.B., P.D. Moskal, Charles D. Dziuban, and L.P. Rumbough (1996), "Gender and Marital Differences for Risk Taking Among Undergraduates," Psychological Reports, 78 (1), 315-320.

Witte, Kim (1992), "Putting the Fear Back into Fear Appeals: The Extended Parallel Process Model," Communication Monographs, 59 (4J, 329-349. 21 Means 21 Campaign (2001), www.coors.com (April 9, 2001). 
NOT THE PUBLISHED VERSION; this is the author's final, peer-reviewed manuscript. The published version may be accessed by following the link in the citation at the bottom of the page.

Table 1

Summary of Findings

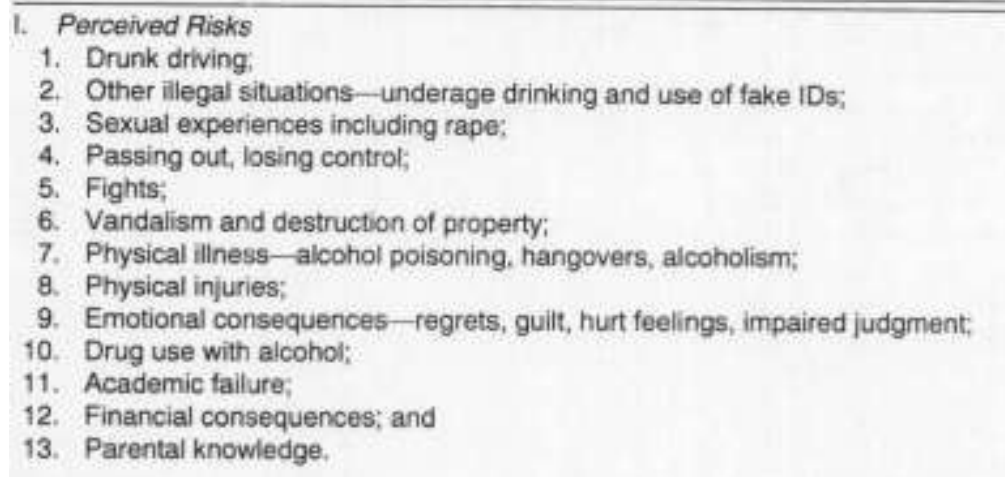

II. Attitudes Regarding Severity

1. The consequences are so minimal.

2. No one disapproves of the consequences.

3. Relatively speaking, drinking is safe.

III. Attitudes Toward Vuinerability

1. We are invincible.

2. Almost all students drink; therefore, it must be o.k.

IV. Response Efficacy for Risk Management

1. Taking chances.

2. Drinking with friends, selecting a "babysitter."

3. Designating a driver.

4. Drinking defensively, avoiding risky situations, walking away from trouble.

5. Knowing your limits, pacing yourself.

V. Attitudes that influence Self-Efficacy

1. Vuinerability to peer pressure.

2. Changes due to age.

VI. Ritual Influences

1. Community.

2. Order.

3. Transformation.

VII. Other Attitudes and Beliefs that Support Ritual Influences

1. Drinking makes for great stories and offers the best memories of college life.

2. We have the freedom to drink.

3. College is the best time in our lives for drinking.

4. Nothing else compares with the sensation or thrill.

5. Drinking allows us to live life to the fullest.

6. Alcohol excuses "bad behavior."

Journal of Advertising, Vol 30, No. 4 (Winter 2001): pg. 23-39. DOI. This article is @ Routledge (M.E. Sharpe) and permission has been granted for this version to appear in e-Publications@Marquette. Routledge (M.E. Sharpe) does not grant permission for this article to be further copied/distributed or hosted elsewhere without the express permission from Routledge (M.E. Sharpe). 
NOT THE PUBLISHED VERSION; this is the author's final, peer-reviewed manuscript. The published version may be accessed by following the link in the citation at the bottom of the page.

Figure 1

Integrated Risk Perception Model

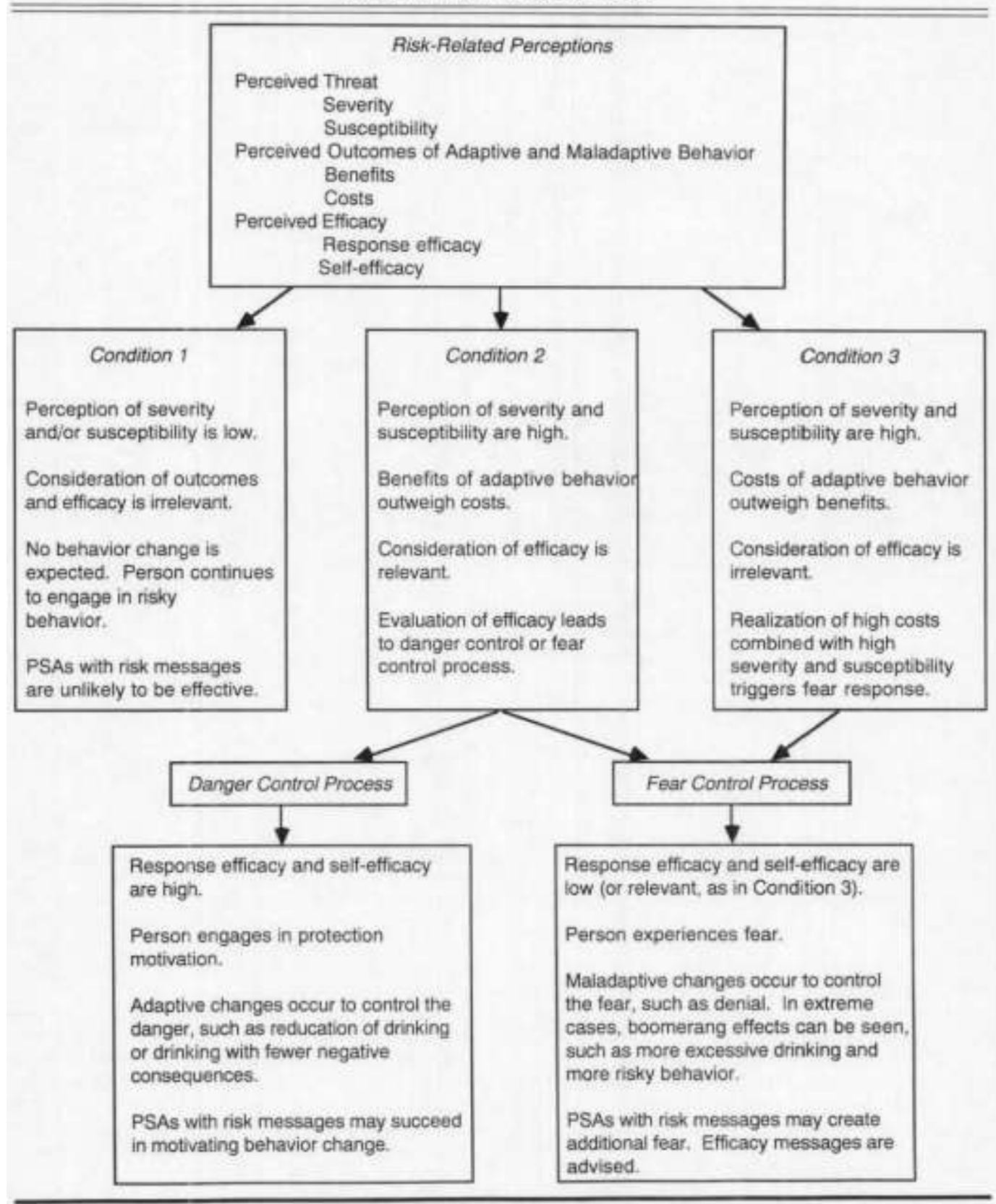

Journal of Advertising, Vol 30, No. 4 (Winter 2001): pg. 23-39. DOI. This article is (C) Routledge (M.E. Sharpe) and permission has been granted for this version to appear in e-Publications@Marquette. Routledge (M.E. Sharpe) does not grant permission for this article to be further copied/distributed or hosted elsewhere without the express permission from Routledge (M.E. Sharpe). 